\title{
Review of Tomáš Sedláček's Economics of good and evil: the quest for economic meaning from Gilgamesh to Wall Street. New York: Oxford University Press, 2011, 384 pp.
}

\author{
JOHAN GRAAFLAND \\ Tilburg University
}

This book is well written and timely. The moralistic response of many politicians and commentators in the public debate about the economic crisis has made economists more interested in the ethical dimensions of economic activity and economic policy-making. With the aid of ancient literature Sedláček explains why ethics has always been important in economics, and why it should be. The old stories show that humans' material desires tend to be boundless, and thus the need for selfcommand and control over material longings if we want to develop a sustainable economy.

By starting from humanity's oldest writings, the author is able to put current economic thought in perspective. In Sedláček's view, knowledge of myths and stories is indispensable, even for economists. Narrow minded economists will never be good economists, because understanding the economy requires going beyond the specifically economic domain. John Maynard Keynes $(1924,322)$ already argued that master-economists "must be mathematician, historian, statesman, philosopher-in some degree". Mathematical models and statistics are merely the tip of the iceberg. Sedláček introduces what he calls 'meta-economics', which includes the historical, cultural, psychological, theological, and philosophical underpinnings of economics. He argues that modern economic theories are new (mathematical) forms of the meta-economic stories found in ancient myths. It is significant that all these stories are basically about good and evil: contemporary economic debate is more about competing stories of good and evil than technical discussions. Economists should be aware of this and stop denying that economics is inherently normative.

The book is composed of two parts. In the first part Sedláček looks for the economics in myths, religion, theology, philosophy, and science. In this part he tries to "tell the story of economics" by analyzing important milestones in the historical development of economic 
thinking, or more specifically, economic ethics. In the second part, he looks for the myths, religion, theology, philosophy, and science still present under the surface of modern economics. In what follows I first provide a critical summary of parts I and II, and then make some more general comments.

Sedláček starts the book with an analysis of the Epic of Gilgamesh, the oldest surviving piece of world literature (dating from around 2000 $\mathrm{BCE}$ ), and its implicit economics. Since there is no secondary literature on the economic meaning of the Gilgamesh epic, Sedláček provides a first explorative analysis. The epic illustrates, among other things, that economic effectiveness often demands suppressing the humanity in labor relations. People should not spend their time and energy on 'unproductive' labor, such as love, friendship, and the like. Still, and partly because of this, the productive economy cannot fully satisfy human desires.

In Chapter 2 Sedláček analyses the Jewish sacred texts retained in the Old Testament of the Christian bible. In contrast to the cyclical perspective found in the Epic of Gilgamesh, the Hebrews believed in historical progress in this world. Paradise is conceived as a place on earth rather than connected to a heavenly afterlife. Wealth is seldom condemned, nor is poverty valorized. Nature is not sacred, although humanity has responsibility to look after the earth and is viewed as a co-creator. In contrast to the Epic of Gilgamesh, good and evil are perceived as integral parts of human life, rather than as exogenous entities. Moral (I would rather say, spiritual) issues are decisive for human history. According to Sedláček, the Old Testament's moral philosophy strikes a compromise between Stoical philosophy (that we should not aim at pleasure, but live according to moral rules) and Epicurean philosophy (that we should maximize utility without need of respecting rules).

Sedláček gives very nice illustrations of the economic relevance of Old Testament stories, like Joseph's grain storage program to prevent famine in Egypt, an early example of economic stabilization policy. That story also illustrates that correct economic predictions of bad outcomes will normally not materialize, because of the very policy measures taken to prevent them. Other economic examples include religiously mandated laws to prevent the concentration of economic wealth and the resulting social inequality (debt bondage); the close connection between charity and responsibility; the holy Sabbath rest as 
an "ontological break"-for the enjoyment of the fruits of our workrather than 'productive' rest that allows one to work more efficiently the rest of the week.

Chapter 3 takes up classical Greek thought. An interesting example is Xenophon, who had already argued in favor of trading relationships with foreigners (instead of war) as a means of progress, stressing the positive sum gains for all involved. He was also aware of the economic benefits of the division of labor, the notion that Adam Smith famously described in his example of the pin factory in the Wealth of nations. Sedláček also discusses important differences between, for example, Plato and Aristotle, and the Stoics and the hedonists.

In chapter 4 Sedláček turns to the New Testament and Christian theology. Generally, I found Sedláček's reading of the Bible very well-informed and his application of it to economic issues very original and refreshing. Sedláček cites authors who argue that socio-economic issues rank as the most important topic in the Bible after idolatry. A major topic is the remission of debts. Often this has a spiritual meaning (forgiveness of $\sin$ ), but the Greek word for sin (as used, for example, in Matthew 6:12) can also be translated as debt (as in Romans 4:4). Thus, the famous prayer in Matthew 6:12 ("Forgive us the wrongs we have done...") has a surprisingly topical ethical precept if one interprets it in an economic sense, as stating "Forgive us our debts, as we also have forgiven our debtors". Although the cancellation of debts seems unfair, in a modern economy just as in a premodern economy, it is sometimes necessary for the survival of society as a whole. Good bankruptcy laws prevent the immiseration of individuals, and also provide incentives to creditors to assess creditworthiness and reduce 'predatory' lending practices.

Sedláček explains how Jesus's command to love each other is also of great value for economic trust and cooperation. For a long time game theorists held that 'an eye for an eye' ("tit for tat") strategy was the most efficient cooperation strategy. But recent research has shown that the 'grace' strategy that Sedláček attributes to Jesus is more promising because it prevents a vicious negative spiral of mutual punishing and hence is more effective in promoting cooperation. Sedláček also derives an important lesson from the parable of the seed (Matthew 13:24-30): good can only grow to fruition if the evil mixed in with it is also allowed to grow. 
In chapter 5 Sedláček highlights the links between the rational philosophy of Descartes and the mathematical and rational method in economics, including the account of rational man (homo economicus).

Chapter 6 provides an interesting analysis of Bernard de Mandeville's (in)famous book The fable of the bees: or, private vices, public benefits. Sedláček portrays Mandeville as criticizing the hypocrisy in society's condemnation of vice. People say they want to rid society of vice, but they also want to live in a great and rich society, for which, Mandeville argues, vices are indispensable as the source of demand for goods or services. That does not mean that Mandeville gives a moral defense of the vices. Mandeville does not judge which society is preferable: the virtuous or the vicious. He only wants to show that vice is inherent to a materially flourishing human society, and so we cannot have both virtues and material prosperity. Interestingly, this point can also be found in the Epic of Gilgamesh and Jesus's parable of the seed, discussed above. Evil cannot be uprooted without destroying the good as well, and thus social planners should instead try to redirect its energy towards good social outcomes.

The way Sedláček links the role of evil to the creation of good is fascinating. It should make us prudent in the way we approach evil. On the other hand, I believe that Sedláček could have been more critical of Mandeville's ideas. He does not pay much attention to recent empirical studies that show that virtues have a directly positive effect on economic development. For example, there is much evidence that trust (social capital) is an important determinant of economic growth (Knack and Keefer 1997; Beugelsdijk, et al. 2004), and it is difficult to see how trust can develop if virtues such as honesty and justice are lacking. Honesty, loyalty, truthfulness, and justice facilitate efficient coordination if individual and common goals are not perfectly aligned and if information is imperfect (Frank 2004, chapter 4). Furthermore, although Sedláček's interpretation of Mandeville is interesting, it is also disputable. Most scholars see Mandeville's charge of hypocrisy as concerning society's implausible definitions of virtue and vice, in which the merest hint of selfishness in one's motivations means one is behaving viciously. Such impossible standards make anyone who claims to be virtuous into a hypocrite.

Chapter 7 on Adam Smith closes the first part of the book. Sedláček discusses Smith's virtue ethics, and the concepts of the impartial spectator and the invisible hand. He compares Smith with Mandeville. 
Although Smith is usually taken to strongly disagree with Mandeville, accusing him of abolishing the distinction between virtue and vice, according to Sedláček Smith's own position is not substantially different. That is because, while Smith turned the vice of self-love into a more neutral concept of self-interest, he nonetheless believed, like Mandeville, that it was such self-interested behavior that generated material prosperity. And although Smith did not perceive self-interest as the most important principle in all human relations, he considered it very important in the economic domain. By reframing Mandeville's moral analysis-by recasting the vice of self-love into the more neutral self-interest-Smith can be seen as making use of parts of Mandeville's economic analysis while avoiding the criticism Mandeville had received. Sedláček does not mean to say, however, that virtues were not important for Smith. He discusses the famous 'Adam Smith problem' and argues that Smith believed that humans are driven by several other motives even stronger than (rational) self-interest.

One can question whether Smith is really so close to Mandeville as Sedláček believes. In Smith's analysis of self-interest in the Theory of moral sentiments, the virtues of prudence and self-command play an important role (e.g., IV.i.17). Smith describes prudence as the exercise of superior reasoning and understanding, by which one discerns the remote consequences of one's actions for one's own happiness. A prudent person will have a clear understanding of their self-interest, and will take account of the interests of others at least insofar as that is instrumental to achieving their goals. Prudence thus prevents clear-eyed self-interest degenerating into delusional self-love. Self-command likewise moderates self-interest and prevents it from degenerating into short-term hedonism. If guided by prudence and self-command, self-interest therefore cannot be equated to the vice of (pure) egoism that aims to maximize one's own happiness without consideration of the interests of others.

Turning now to the second part of the book, in which the myths in economics are investigated, the first theme is greed. According to the story of Genesis 2, evil entered the world through greed. Although the supply of food in paradise was abundant, Adam and Eve were not satisfied and wanted more. According to the Epic of Gilgamesh, becoming aware of unmet needs stimulates culture. The dissatisfaction caused by discovering new needs stimulated the savage Enkidu to enter civilization. In his natural state, a human being hardly has more needs 
than a wild animal, but when he develops civilization his wants multiply together with his means of meeting them. As Sedláček quotes Frank Knight, "[I]t is human nature to be more dissatisfied the better off one is". The questions that Sedláček then raises are to what extent we must accept this human craving for more, and how we can put limits on our desires.

Chapter 9 is about progress and whether that requires continuous economic growth or the economics of enough. Sedláček describes the hopes of J. S. Mill (in his well-known Principles of political economy, section 4.6) and J. M. Keynes (in his essay Economic possibilities for our grandchildren) that economic progress would eventually solve the economic problem and lead to a stationary zero-growth economy in which everyone would be able to live a life that is good, in both material and moral terms. Historically, Western society has never been as rich as today. But Keynes's prediction has not yet come true. Moreover, beyond a certain level national opulence does not seem to substantially increase (average) individual happiness, a finding that is also found at the micro level. According to Sedláček growth then becomes meaningless. It seems that we carry with us a persistent dissatisfaction with what we have that drives us to keep moving and striving for more. But this continuous pursuit of more material prosperity by individuals comes at the cost of their true peacefulness and even their enjoyment of the satisfaction of their desires. It is difficult to follow the Stoics' advice to be content with what we have. But if we did, we would probably have much more leisure and less working stress.

Chapters 10 to 12 explore Smith's invisible hand, homo economicus, and Keynes's animal spirits. Sedláček shows that, long before Smith, other authors had already expressed ideas very similar to his invisible hand mechanism. In contrast to Sedláček, I believe that the use of the notion of the invisible hand by Smith in the Theory of moral sentiments comes very close to his use of it in the Wealth of nations. The underlying idea is that divine Providence has implanted in human nature such sentiments as tend to bring about the happiness and welfare of mankind. In his discussion of the invisible hand, Sedláček also refers to Paul (Romans 7:21-25). Sedláček interprets this text as evidence that Paul was aware that good intentions may have evil consequences (i.e., the opposite of Mandeville's private vices, public benefits thesis). I wonder, however, whether Paul means to say this. This text is not 
about the distinction between good intentions and good consequences, but about the inner conflict between the spirit and the flesh.

Chapter 11 ends by discussing Robert Nelson's claim that while self-interest contributes to economic prosperity, excessive self-interest undermines the proper functioning of the market economy. This suggests a curvilinear relationship between self-interest and social welfare. Chapter 12 deals with Keynes's notion that irrational animal spirits (described as spontaneous impulses to act not guided by quantitative deliberations) are necessary for entrepreneurial activity. Given irremediable uncertainty about the future, the rational selfinterest attributed to homo economicus is insufficient to justify business initiatives. Human beings need both.

In chapters 13 and 14, Sedláček criticizes the large role of mathematics in economics. Because of their mathematical methodology, economists often lack a broader social vision of the economy. Economists should also be more modest in their claims, given the low predictive power of mathematical economics. The future is radically indeterminate. Only the static, non-living part of reality is predictable. When economists discuss actual economic policy, the mathematical models should be put aside. In the last chapter, Sedláček therefore concludes by returning to his central message: for the study of economic problems meta-economics-including philosophy, theology, anthropology, history, psychology, sociology, and other disciplines-is indispensable.

I agree with Sedláček that economics should not be limited to mathematical models. However, I believe that in the practice of economic policy mathematical economic models do not actually play such a large role. I know from my own experience as a model builder at the CPB (the Netherlands Bureau for Economic Policy Analysis, an independent government agency founded by Jan Tinbergen) that practical (non-abstract) and qualitative information about the economy is at least as important. Moreover, the limitations of mathematical models are already well known and economists have come to pay much more attention to empirical analysis (and the development of good data sources) and the qualitative analysis of institutions during the last decades. The boundedness of human rationality is also now widely recognized in economics (behavioral economics) and already influences policy advice, for example regarding pension systems. However, it is 
true that the translation of such realistic theories into policy analysis is still too limited.

Sedláček delves into ancient writings to provide us a positive view on life, while also recognizing the dark side of human nature and evil. The result is very inspiring. Nevertheless, the book leaves me with a number of questions. First, it is not entirely clear whether or how Sedláček thinks humans can escape the restless search for more. If we do not know what we want, how can we limit our wants? What kind of economic behavior does Sedláček want to encourage? How can we stimulate a change in mindset, to learn to be content and enjoy what we already have rather than 'maximize'? On the macroeconomic level, this question leads me to wonder whether a stationary economy is feasible or desirable. From a Christian ethical perspective, I would rather stress the need for selective growth that really serves human needs and raises the quality of life, rather than an economics of mere sufficiency. Making progress on the aspects of human life that matter is a good goal to have, and it calls upon part of humanity's creative nature (Graafland 2010, 49-54). In the Bible, work is seen as a calling and as a service to others. One should develop one's talents and use the income that they generate not only for oneself, but also for those in need. In a modern society this Christian calling to serve others implies support for institutions that aim to guarantee a reasonable quality of life for everyone in society.

Second, although I fully agree that ethics is, and should be recognized as, an integral part of the economy and hence of economics, the influence of ethics may nonetheless be limited. The market seems to have its own pernicious logic of greed, capable of surviving the social and political condemnation associated with the current economic crisis and even the moralizing of economists themselves. For example, Joseph Stiglitz (2012) has argued that concentrations of wealth lead to concentrations of political power which give the rich substantial control over economic institutions and government policies and allow them to become rentier capitalists at the expense of both aggregate economic growth and its equitable distribution. It would be interesting to analyze the failure of such ethical arguments throughout history to overcome the corruption they condemn.

Sedláček rightly stresses the importance of stories, and it is very interesting to read about the economic implications of different ancient myths and stories. Stories are indeed still important in today's business 
and politics. But obviously the inspiration that stories give can go in all kinds of direction. Alan Greenspan, for example, has stated that he was inspired by stories in making economic policy as chairman of the Federal Reserve System, namely by the books and philosophy of Ayn Rand. We cannot escape the problem of how to make best use of the stories we have inherited and their ethical or economic lessons. Although Sedláček helps the reader to recognize that economics is filled with value-laden stories and thus to overcome the "self-inflicted blindness" of contemporary economics, he does not deal with the moral question of which stories should be guiding us.

\section{REFERENCES}

Beugelsdijk, Sjoerd, Henry de Groot and Ton van Schaik. 2004. Trust and economic growth: a robustness analysis. Oxford Economic Papers, 56 (1): 118-134.

Frank, Robert. 2004. What price the moral high ground? How to succeed without selling your soul. Princeton: Princeton University Press.

Graafland, Johan. 2010. The market, happiness, and solidarity: a Christian perspective. London: Routledge.

Keynes, John M. 1924. Alfred Marshall, 1842-1924. The Economic Journal, 34 (135): 311-372.

Knack, Stephen, and Philip Keefer. 1997. Does social capital have an economic payoff? A cross-country investigation. The Quarterly Journal of Economics, 112 (4): 12511288.

Smith, Adam. 1759. The theory of moral sentiments. New York: Prometheus.

Stiglitz, Joseph. 2012. The price of inequality. London: Penguin Books.

Johan Graafland is professor in economics, business, and ethics at Tilburg University, The Netherlands. His research focuses on the fields of macroeconomic ethics, business ethics/corporate social responsibility, and the Christian view of the economy. His most recent book is The market, happiness, and solidarity: a Christian perspective (Routledge, 2010).

Contact email: $<$ j.j.graafland-at-uvt.nl $>$ 